\title{
Debranching Enzymes of Potato Tubers (Solanum tuberosum L.). I. Purification and Some Properties of Potato Isoamylase
}

\author{
Yukuo IshizaKI, ${ }^{*}$ Hajime Taniguchi, Yoshiharu MaruYama \\ and Michinori NAKAmURA** \\ Department of Agricultural Chemistry, The University of Tokyo, \\ Bunkyo-ku, Tokyo 113, Japan \\ Received August 30, 1982
}

\begin{abstract}
Potato tubers contain 3 debranching enzymes separable by polyacrylamide gel electrophoresis. One of them, isoamylase, has been purified to apparent homogeneity on disc gel electrophoresis by isoelectric precipitation, fractionation with ammonium sulfate, gel filtration on Sepharose $6 \mathrm{~B}$ and finally affinity chromatography on Sepharose $4 \mathrm{~B}$-soluble starch, successively. The purified enzyme has a specific activity of $8.0 \mathrm{U} / \mathrm{mg}$ of protein. It hydrolyzes the $\alpha-1,6$-glucosidic bonds in glycogen and phytoglycogen not only as rapidly as those in amylopectin but also completely, but cannot hydrolyze pullulan. From these results potato isoamylase was found to have the same substrate specificity as that of Pseudomonas isoamylase. However, different from the latter, it has an optimum $\mathrm{pH}$ of $5.5 \sim 6.0$, optimum temperature of $50^{\circ} \mathrm{C}$ and was reversibly inactivated by $p$-chloromercuribenzoate.
\end{abstract}

Debranching enzymes, which hydrolyze $\alpha$ 1,6-glucosidic linkages in amylaceous polysaccharides, are widely distributed in nature and play an important role in the complete hydrolysis of these polysaccharides. ${ }^{1)}$ These debranching enzymes can be classified into 3 groups; pullulanases (R-enzyme), isoamylases and amylo-1,6-glucosidases, according to their substrate specificity. Amylo-1,6-glucosidase (EC 3.2.1.33) is found in mammals and yeast and hydrolyzes $\alpha$-1,6-glucosidic linkages in phosphorylase limit dextrin. Pullulanase (EC 3.2.1.41) has been the most extensively studied debranching enzyme which hydrolyzes $\alpha-1,6-$ glucosidic linkages in amylopectin, its $\beta$-limit dextrin and pullulan but hardly acts on glycogen. This type of debranching enzyme is found in microorganisms and higher plants. The enzyme in higher plants is often called Renzyme. Isoamylase (EC 3.2.1.68) has been found in microorganisms. The enzyme from Pseudomonas $\mathrm{sp}^{2)}$ has especially been studied extensively. This type of enzyme hydrolyzes amylopectin as rapidly as pullulanase does. However, different from the latter, the former cannot hydrolyze pullulan but instead hydrolyzes glycogen completely.

Since R-enzyme was found in potato tubers by Hobson et al., ${ }^{3)}$ increasing numbers of debranching enzymes have been found in various higher plants. ${ }^{4 \sim 7)}$ Except for sweet corn isoamylase reported by Manners and Rowe, ${ }^{8)}$ all these debranching enzymes were classified as the pullulanase type.

We have studied the starch-metabolizing enzymes in potato tubers and found that these tissues contain an isoamylase in addition to the long known pullulanase. This paper deals with the purification and some properties of the isoamylase from potato tubers. A preliminary report of this work has already been published..$^{9)}$ The purification of a pullulanase from potato tubers together with a comparative study of the potato isoamylase and pullulanase will be published elsewhere. ${ }^{10)}$

* Present address: Central Research Laboratories, Takara Shuzo Co., Ltd., Otsu, Shiga 520-21, Japan.

** Present address: Tokyo University of Agriculture, Sakuragaoka, Setagaya-ku, Tokyo 156, Japan. 


\section{MATERIALS AND METHODS}

Materials. Potato tubers (Solanum tuberosum L. cul. var. "Danshaku") were obtained from a local market in Tokyo and kept at $4^{\circ} \mathrm{C}$ before use. Tubers of several relatives of the cultivar, Solanum demmisum, S. rybinii, $S$. andigena, $S$. stenotomum and $S$. phureja, were generous gifts from Dr. K. Asama of the Konsen Agricultural Experimental Station, Hokkaido. Maltose, maltotriose, short chain amylose (DP $\doteqdot 17)$ and pullulan were purchased from Hayashibara Biochemical Lab. Inc., Okayama. Maltopentaose was obtained from Seishin Pharmaceutical Co. Ltd., Noda-shi, Chiba. Phytoglycogen was prepared from sweet corn by the conventional method in this laboratory. $\beta$-Limit dextrins of amylopectin, phytoglycogen and oyster glycogen were gifts from Dr. I. Maeda of Konan Women's Junior College, Aichi. Pepstatin was purchased from the Peptide Institute, Osaka. Standard proteins for molecular weight determination were obtained from Boehringer Mannheim Japan or Sigma Chemical Co. All other chemicals were obtained from usual commercial sources.

Analytical methods. The amount of reducing sugars was determined by the method of Somogyi ${ }^{11)}$ and Nelson, ${ }^{12)}$ with the boiling time being increased to $30 \mathrm{~min}^{13}$ ) The amount of total sugars was determined by the phenolsulfuric acid method. ${ }^{14)}$ Protein content was determined by the method of Lowry et al. ${ }^{15)}$ using bovine serum albumin as a standard. For the routine assay of protein in the column eluate, the absorbance at $280 \mathrm{~nm}$ was measured with a Shimadzu UV-140 spectrophotometer.

\section{Assay of isoamylase activity.}

Assay 1. The enzyme solution to be tested was preincubated in $5 \mathrm{~mm}$ 2-mercaptoethanol (2ME) at $30^{\circ} \mathrm{C}$ for $10 \mathrm{~min}$. Fifty $\mu \mathrm{l}$ of the preincubated enzyme solution was added to $200 \mu \mathrm{l}$ of $1.25 \%$ amylopectin solution in $50 \mathrm{~mm}$ acetate buffer ( $\mathrm{pH}$ 6.0) and the enzymic reaction was allowed to proceed at $30^{\circ} \mathrm{C}$ for $15 \mathrm{~min}$. The amount of reducing sugars produced was determined as described above. One unit of isoamylase activity was defined as the amount of the enzyme that released $1 \mu \mathrm{mol}$ of glucose equivalent per min under the above conditions. Specific activity is given as units of enzyme activity per $\mathrm{mg}$ of protein.

Assay 2. For the activity assay of the column eluates, $100 \mu \mathrm{l}$ of suitably diluted column eluate was incubated with $100 \mu \mathrm{l}$ of $1 \%$ amylopectin in $100 \mathrm{~mm}$ acetate buffer (pH 6.0 ) at $30^{\circ} \mathrm{C}$. One $\mathrm{ml}$ of $0.04 \% \mathrm{I}_{2}-0.4 \% \mathrm{KI}$ solution was added after $30 \mathrm{~min}$ incubation to develop the iodine stain. Two $\mathrm{ml}$ of distilled water was further added and the color intensity was measured at $600 \mathrm{~nm}$.

Disc electrophoresis. Polyacrylamide gel electrophoresis was performed essentially as described by Davis, ${ }^{16)}$ using Tris-glycine buffer ( $\mathrm{pH}$ 8.3). After electrophoresis, one of the gels was stained for protein with Coomassie Brilliant Blue R-250. Another gel was immersed in $0.5 \%$ agar solution containing $1 \%$ starch in $50 \mathrm{~mm}$ acetate buffer $(\mathrm{pH}$ 6.0) just before gelation and kept at $30^{\circ} \mathrm{C}$ for $1 \mathrm{hr}$. The gel was then removed from the agar plate and reducing sugars produced by the enzymic action were stained with triphenyltetrazolium chloride as described by Gabriel and Wang. ${ }^{17)}$ SDS polyacrylamide gel electrophoresis was carried out according to the method of Weber and Osborn ${ }^{18)}$ using an acrylamide concentration of $5 \%$. Protein samples were previously heated at $100^{\circ} \mathrm{C}$ for $5 \mathrm{~min}$ in the presence of $1 \%$ SDS and $200 \mathrm{~mm} 2 \mathrm{ME}$.

Paper chromatography. Ten $\mu \mathrm{l}$ of the reaction mixture containing $50 \mu \mathrm{g}$ of polysaccharides was spotted on Tôyô Filter Paper No. $50(20 \times 20 \mathrm{~cm})$ and the paper was irrigated with $65 \% 1$-propanol at $70^{\circ} \mathrm{C}$. by the double ascending method. The paper was dried, treated with glucoamylase $^{19)}$ and reducing sugars on the paper were detected by the alkaline-silver nitrate ${ }^{20)}$ dip method.

Preparation of affinity gel. Sepharose 4B was activated with bisoxirane [1,4-bis(2,3-epoxypropoxy)-butane] according to the method of Sundberg and Porath. ${ }^{21)}$ Polyand oligosaccharides to be tested as ligands were coupled to this activated Sepharose according to the method of Vretblad. $^{22)}$

\section{RESULTS}

\section{Purification of isoamylase.}

Potato tubers $(7.5 \mathrm{~kg})$ were washed, peeled and cut into small pieces. Every 400.g of the tubers was homogenized in a juicer with the same volume of $10 \mathrm{~mm}$ calcium acetate containing $50 \mathrm{~mm} 2 \mathrm{ME}$ to prevent browning of the extracts and to activate isoamylase. The homogenate was immediately filtered on a Büchner funnel to remove cell debris and starch granules and the resulting filtrate was centrifuged at $10,000 \times g$ for $30 \mathrm{~min}$. The supernatant obtained (crude extracts, $\mathrm{pH}$ 6.0) was adjusted to $\mathrm{pH} 5.0$ with $7 \%$ acetic acid and the solution was immediately centrifuged at $10,000 \times g$ for $30 \mathrm{~min}$ to precipitate isoamylase. Pullulanase does not precipitate at this $\mathrm{pH}$ and, therefore, isoamylase essentially free from pullulanase was obtained (Fig. 11). The precipitate was dissolved in 1.5 liters of $10 \mathrm{~mm}$ citrate buffer $(\mathrm{pH} 6.7)$ containing $10 \mathrm{~mm} 2 \mathrm{ME}$ and $1 \mu \mathrm{M}$ pepstatin (Buffer A, pepstatin was added to prevent 
protease action.) and the solution was stirred overnight to ensure dissolution of isoamylase. Insoluble materials were centrifuged off if present and the supernatant was brought to $40 \%$ saturation with respect to $\left(\mathrm{NH}_{4}\right)_{2} \mathrm{SO}_{4}$. After $1 \mathrm{hr}$ of standing, the precipitate was collected by centrifugation, dissolved in $300 \mathrm{ml}$ of Buffer $\mathrm{A}$ and dialyzed overnight against the same buffer. The dialyzate was subjected to second $\left(\mathrm{NH}_{4}\right)_{2} \mathrm{SO}_{4}$ precipitation by adding a saturated solution. Isoamylase was precipitated by $30 \%$ saturation and the precipitate was collected, dissolved and dialyzed as described above.

The second dialyzate $(14.8 \mathrm{ml})$ was applied on a column $(3.6 \times 70 \mathrm{~cm})$ of Sepharose $6 \mathrm{~B}$ previously equilibrated with $10 \mathrm{~mm}$ citrate buffer ( $\mathrm{pH}$ 6.7) containing $5 \mathrm{~mm} 2 \mathrm{ME}$ (Buffer B) and the protein was eluted with the same buffer. Ten $\mathrm{ml}$ fractions were collected and protein and isoamylase activity in each fraction were followed by the absorbance at $280 \mathrm{~nm}$ and the iodine staining method, respectively. A typical elution pattern is presented in Fig. 1. Active fractions (Frs. 42 49) were collected, concentrated to $13.3 \mathrm{ml}$ with an Amicon XM-100 membrane and subjected to affinity chromatography using sugar-coupled Sepharose 4B.

Soluble starch, amylopectin $\beta$-limit dextrin, short chain amylose $(\mathrm{DP} \doteqdot 17)$ and maltopentaose were tested as ligands for isoamylase after being coupled to Sepharose 4B, respectively. As shown in Table I, Sepharose 4Bsoluble starch was found to be the most effective as a ligand and, therefore, used in the following experiments. Four $\mathrm{ml}$ portions of the concentrate obtained above were applied on a column $(9 \times 20 \mathrm{~cm})$ of Sepharose 4Bsoluble starch previously equilibrated with Buffer B. After the column was washed with the same buffer to elute inactive proteins, the enzyme was eluted with Buffer B containing $2 \%$ dextrin (British Gum). Three ml fractions were collected and the protein content and isoamylase activity in each fraction were determined as described above. A typical elution pattern is presented in Fig. 2. The enzyme

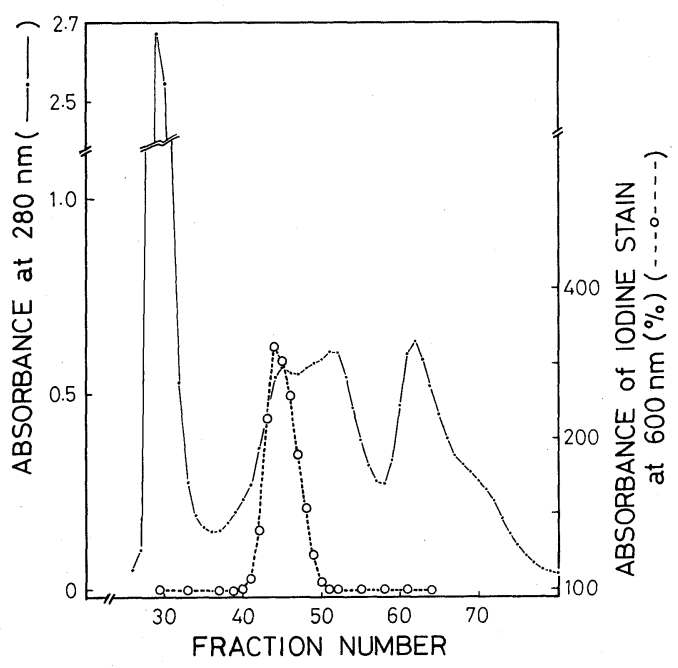

FIG. 1. Gel Filtration of Potato Isoamylase on Sepharose 6B.

The dialyzed enzyme preparation $(14.8 \mathrm{ml})$ was applied on a column $(3.6 \times 70 \mathrm{~cm})$ of Sepharose $6 \mathrm{~B}$ previously equilibrated with Buffer B. Proteins were eluted $(20 \mathrm{ml} / \mathrm{hr})$ with the same buffer and protein and isoamylase activity in $10 \mathrm{ml}$ fractions were followed by measuring the absorbance at $280 \mathrm{~nm}$ and by assay 2 , respectively.

TABle I. ADSORption OF Potato IsOAmylase to the Sepharose 4B-Immobilized Sugars

Portions $(2.14 \mathrm{U})$ of the isoamylase preparation obtained from the Sepharose $6 \mathrm{~B}$ column were applied to columns $(9 \times 20 \mathrm{~cm})$ of Sepharose $4 \mathrm{~B}$-immobilized sugars previously equilibrated with Buffer B. Each column was washed $(10 \mathrm{ml} / \mathrm{min})$ with 5 column volumes of the buffer and the activity in each washing was assayed by assay method 1 .

\begin{tabular}{lc}
$\begin{array}{c}\text { Immobilized sugars } \\
\text { on Sepharose 4B }\end{array}$ & $\begin{array}{c}\text { Isoamylase adsorbed } \\
(\%)\end{array}$ \\
\hline None & 0 \\
Soluble starch & 93 \\
Amylopectin $\beta$-LD & 31 \\
Amylose (DP $\doteqdot 17)$ & 25 \\
Maltopentaose & 35 \\
\hline
\end{tabular}

preparation thus obtained showed a single band of protein and activity on polyacrylamide gel electrophoresis as shown in Fig. 3 and was used in the following experiments.

During the above purification procedures, whenever the enzyme solution was left exposed to the air for a long time (for instance, dialysis 


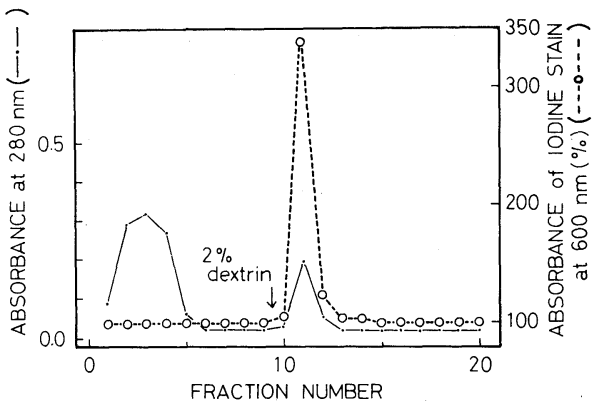

FIG. 2. Affinity Chromatogram of the Isoamylase on Sepharose 4B-Soluble Starch.

A quarter $(4 \mathrm{ml}, 10 \mathrm{U})$ of the pooled fraction obtained in Fig. 1 was applied to a column $(9 \times 20 \mathrm{~mm})$ of Sepharose 4B-soluble starch previously equilibrated with Buffer B. After washing with the same buffer, the enzyme was eluted $(10 \mathrm{ml} / \mathrm{hr}$ ) with the buffer containing $2 \%$ dextrin (British Gum). Three $\mathrm{ml}$ fractions were collected and protein and activity in fractions were followed as described in the legend to Fig. 1.

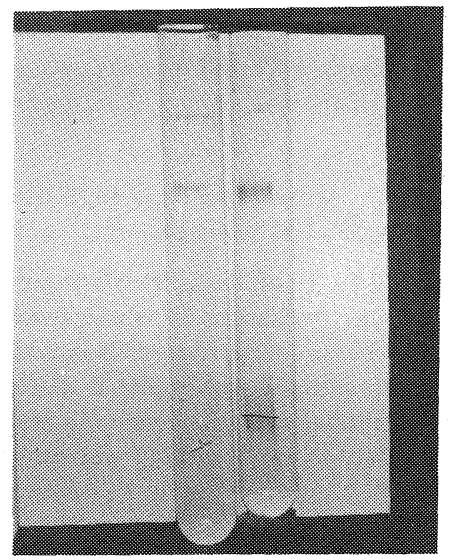

FIG. 3. Polyacrylamide Gel Electrophoresis of the Purified Potato Isoamylase.

Twenty-three $\mu \mathrm{g}$ of protein was applied per gel. Left, protein staining; right, activity staining. and chromatography), fresh concentrated $2 \mathrm{ME}$ was added to a final concentration of $10 \mathrm{~mm}$ before the enzyme solution was subjected to the next purification steps.

The results of purification are summarized in Table II. The enzyme was purified 1300 -fold over the crude extracts and the purified enzyme had a specific activity of $8.0 \mathrm{U} / \mathrm{mg}$ of protein.

\section{Molecular weight of the isoamylase}

The molecular weight of the purified enzyme was determined by gel filtration on Sephadex G-200. As shown in Fig. 4, the value of 520,000 daltons was obtained. This value is extraordinarily high as the molecular weight of a starch-metabolizing enzyme. On the other hand, the enzyme revealed 2 protein bands on SDS polyacrylamide gel electrophoresis as

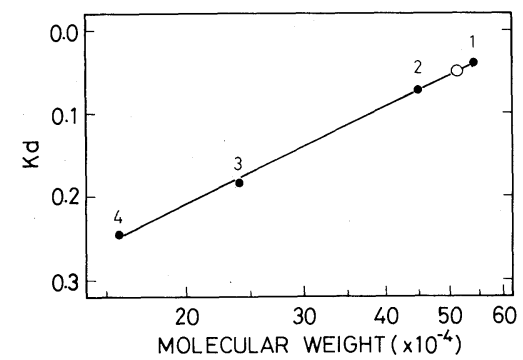

FIG. 4. Estimation of the Molecular Weight of the Purified Potato Isoamylase by Gel Filtration on Sephadex G-200.

Gel filtration was carried out in $40 \mathrm{~mm}$ phosphate-citrate buffer ( $\mathrm{pH} 7.0$ ) containing $0.1 \mathrm{M} \mathrm{NaCl}$ and $10 \mathrm{mM} 2 \mathrm{ME}$ at a flow rate of $2 \mathrm{ml} / \mathrm{hr}$. Standard proteins used were; $1, \beta$ galactosidase $(\mathrm{MW}=540,000), 2$, ferritin $(450,000), 3$, catalase $(240,000), 4$, aldolase $(160,000)$. The open circle denotes the potato isoamylase.

Table II. Summary of the Purification of Potato Isoamylase

\begin{tabular}{lccccc}
\hline Purification step & $\begin{array}{c}\text { Total } \\
\text { activity } \\
(\mathrm{U})\end{array}$ & $\begin{array}{c}\text { Total } \\
\text { protein } \\
(\mathrm{mg})\end{array}$ & $\begin{array}{c}\text { Specific } \\
\text { activity } \\
(\mathrm{U} / \mathrm{mg})\end{array}$ & $\begin{array}{c}\text { Degree of } \\
\text { purification }\end{array}$ & $\begin{array}{c}\text { Yield } \\
(\%)\end{array}$ \\
\hline Crude extracts & 330 & 53200 & 0.0062 & 1 & 100 \\
pH 5 ppt. & 137 & 6590 & 0.0197 & 3.2 & 41.5 \\
$0 \sim 40 \%\left(\mathrm{NH}_{4}\right)_{2} \mathrm{SO}_{4}$ & 121 & 1340 & 0.090 & 14.6 & 36.7 \\
$0 \sim 30 \%\left(\mathrm{NH}_{4}\right)_{2} \mathrm{SO}_{4}$ & 34.9 & 222 & 0.157 & 25.5 & 10.6 \\
Sepharose 6B & 39.0 & 41.3 & 0.943 & 153 & 11.8 \\
Sepharose 4B-sol. starch & 12.7 & 1.59 & 8.00 & 1300 & 3.8 \\
\hline
\end{tabular}


shown in Fig. 5A. The molecular weights of these bands were calculated to be 95,000 and 83,000 from the calibration curve shown in Fig. 5B. The smallest molecular weight of the native enzyme, therefore, is considered to be 178,000 daltons.

\section{Optimum $\mathrm{pH}$}

As illustrated in Fig. 6, the enzyme shows a rather broad $\mathrm{pH}$-activity curve, its maximum

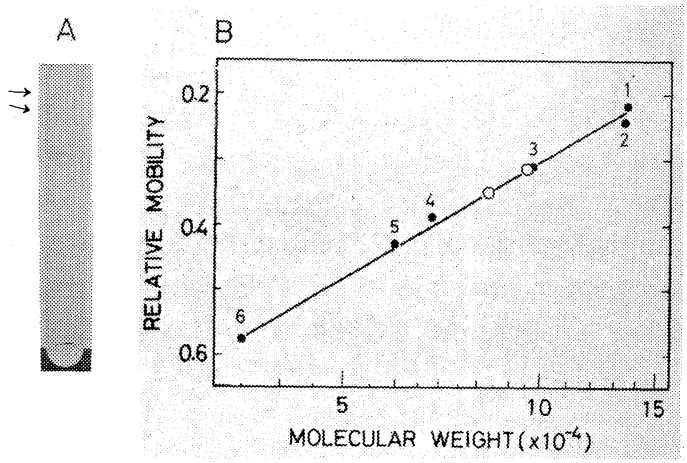

FIG. 5. SDS Polyacrylamide Gel Electrophoresis of the Purified Potato Isoamylase.

A. The protein sample $(20 \mu \mathrm{g} / \mathrm{gel})$ was previously heated at $100^{\circ} \mathrm{C}$ for $5 \mathrm{~min}$ in the presence of $1 \% \mathrm{SDS}$ and $200 \mathrm{~mm}$ $2 \mathrm{ME}$ and then subjected to the electrophoresis.

B. Estimation of the molecular weight of denatured isoamylase. Standard proteins with their subunit molecular weights were: 1 , bovine serum albumin $(68,000)$ dimer; 2 , $\beta$-galactosidase $(135,000) ; 3$, phosphorylase $b(97,000) ; 4$, bovine serum albumin $(68,000) ; 5$, catalase $(60,000) ; 6$, lactate dehydrogenase $(35,000)$. Open circles denote the 2 bands of isoamylase observed in Fig. 5A.

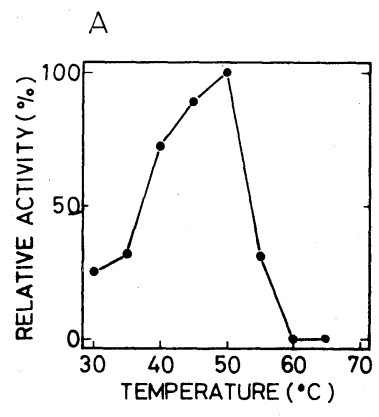

activity being observed at between $\mathrm{pH} 5.5$ and 6.0 .

\section{Optimum and stable temperatures}

As shown in Fig. 7A, the enzyme showed the maximum activity at $50^{\circ} \mathrm{C}$ under the assay conditions used. When incubated in the absence of substrate for $10 \mathrm{~min}$, the enzyme was stable only up to $45^{\circ} \mathrm{C}$ and lost approximately $50 \%$ of its original activity at $50^{\circ} \mathrm{C}$ as illustrated in Fig. 7B.

\section{Effect of Triton $X-100$}

Triton X-100 has an activating effect on the isoamylase activity when present in the prein-

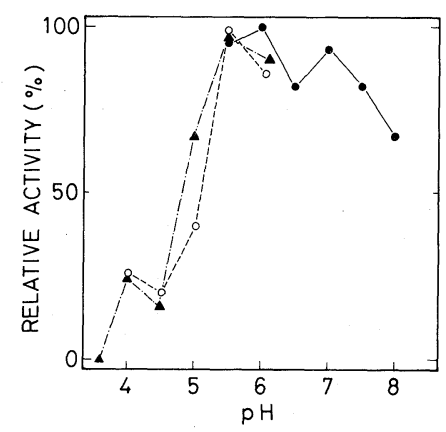

FIG. 6. Influence of $\mathrm{pH}$ on the Activity of Potato Isoamylase.

Activity was assayed by assay method 1 except that the following buffers were used. Open circles, $50 \mathrm{~mm}$ acetate buffer, closed circles, $50 \mathrm{~mm}$ phosphate buffer, triangles, $50 \mathrm{~mm}$ citrate buffer.

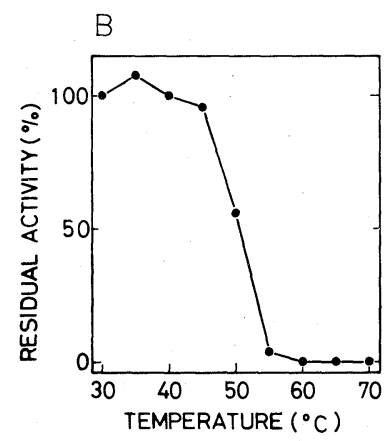

FIG. 7. Influence of Temperature on the Activity and Stability of Potato Isoamylase.

A. Influence on the activity. Activity was assayed by assay method 1 except that the incubation was carried out at various temperatures.

B. Influence on the stability. The enzyme was preincubated in $40 \mathrm{~mm}$ acetate buffer (pH 6.0) at various temperatures for $10 \mathrm{~min}$ and then assayed by assay method 1 . 
TABLE III. EFFECT OF TRITON X-100 ON THE ISOAMYLASE ACTIVITY

Isoamylase $(5.2 \mathrm{mU})$ was preincubated in $40 \mathrm{~mm}$ acetate buffer ( $\mathrm{pH}$ 6.0) containing Triton $\mathrm{X}-100$ at the concentrations indicated below. After preincubation for $30 \mathrm{~min}$ at $30^{\circ} \mathrm{C}$, the remaining activity was assayed as described in Materials and Methods. Remaining activity of the enzyme preincubated without Triton X-100 was taken as $100 \%$.

\begin{tabular}{cc}
$\begin{array}{c}\text { Concentration of } \\
\text { Triton X-100 } \\
(\%)\end{array}$ & $\begin{array}{c}\text { Relative } \\
\text { activity } \\
(\%)\end{array}$ \\
\hline 0 & 100 \\
0.05 & 145 \\
0.10 & 161 \\
0.20 & 159 \\
0.50 & 172 \\
1.00 & 159 \\
\hline
\end{tabular}

cubation mixture. Table III indicates that this reagent at concentrations from 0.05 to $1.0 \%$ activated the enzyme by $45 \sim 72 \%$.

\section{Substrate specificity}

The paper chromatogram shown in Fig. 8 indicates that our isoamylase preparation has the same substrate specificity as that of Pseudomonas isoamylase. Namely, it does not act on pullulan, acts on oyster glycogen as well as amylopectin and produces much more maltotriose than maltose from amylopectin $\beta$-limit dextrin. As was expected, the enzyme preparation has no action on amylose. Figure 9 shows the spectra of iodine staining of amylopectin and oyster glycogen during their isoamylase treatment. With both substrates, the absorbance increased and the wavelength of maximum absorption shifted to a longer wave-

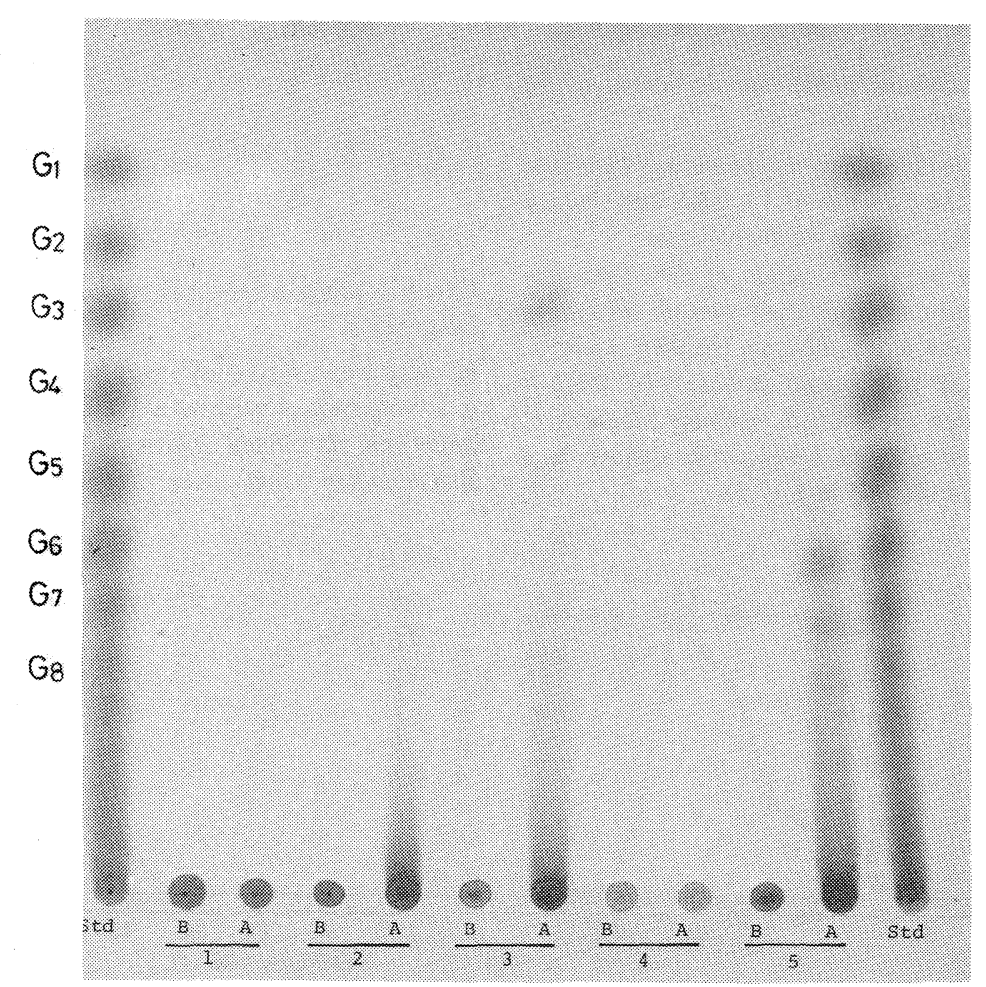

FIG. 8. Paper Chromatogram of the Reaction Products of Isoamylase from Various Polysaccharides.

Isoamylase ( $3 \mathrm{mU}$ ) was incubated with $1 \%$ polysaccharides in $25 \mathrm{~mm}$ acetate buffer $(\mathrm{pH} 6.0)$ for $24 \mathrm{hr}$ at $30^{\circ} \mathrm{C}$. Ten $\mu$ portions were withdrawn from each reaction mixture before (B) and after (A) the incubation and submitted to paper chromatography. Numbers 1 to 5 stand for amylose $(\mathrm{DP} \doteqdot 17)$, amylopectin, amylopectin $\beta$-LD, pullulan and oyster glycogen, respectively. 


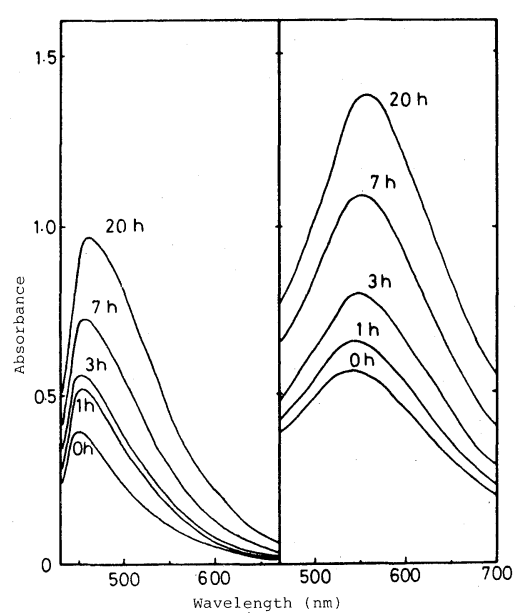

FIG. 9. Increase of Iodine Staining of Glycogen and Amylopectin during Isoamylase Action.

Forty mg of each polysaccharide was incubated with $36 \mathrm{mU}$ isoamylase in $5 \mathrm{ml}$ of $40 \mathrm{~mm}$ acetate buffer ( $\mathrm{pH} \mathrm{6.0)}$ at $30^{\circ} \mathrm{C}$. At intervals, $1 \mathrm{ml}$ portions of the reaction mixtures were withdrawn and added to $4 \mathrm{ml}$ of $0.002 \% \mathrm{I}_{2}-$ $0.02 \%$ KI solution. The developed color of each sample was scanned with a spectrophotometer. Left, oyster glycogen; right, amylopectin.

length as the enzymic reaction proceeded. The time course of the action of the enzyme on amylopectin, oyster glycogen, phytoglycogen and their $\beta$-limit dextrins is shown in Fig. 10. Phytoglycogen and oyster glycogen were hydrolyzed at approximately the same rate as that of amylopectin. $\beta$-Limit dextrins were hydrolyzed at slower rates than those of the polysaccharides from which they were formed, respectively. Pullulan was not hydrolyzed at all in accordance with the result shown in Fig. 8. All these results indicate that potato isoamylase has a quite similar substrate specificity to that of Pseudomonas isoamylase.

\section{DISCUSSION}

The debranching enzyme purified in this work hydrolyzes glycogen completely (see Table V of ref. 10) and as rapidly as amylopectin but does not act on pullulan. Furthermore, it hydrolyzes $\beta$-limit dextrins slower than their original polysaccharides forming maltotriose as the main reaction product. All these results

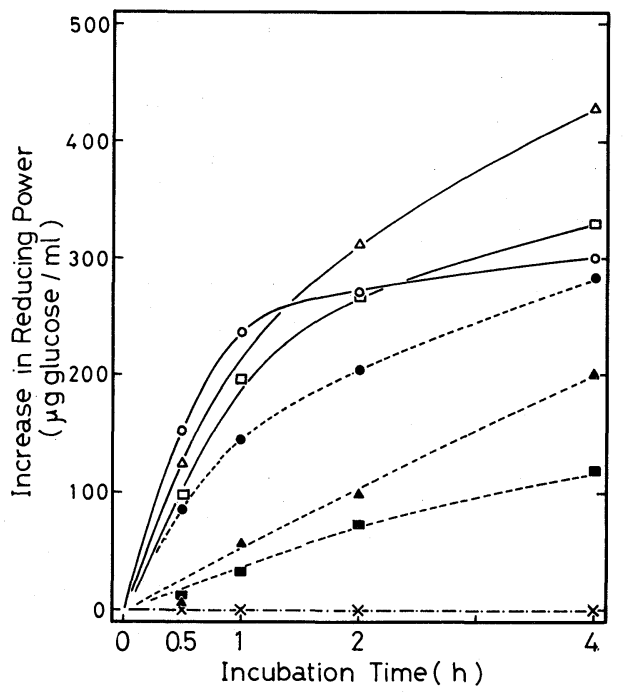

Fig. 10. Hydrolysis Curves of Various Polysaccharides for the Potato Isoamylase.

Ten $\mathrm{mg}$ of each polysaccharide was incubated with $21 \mathrm{mU}$ of isoamylase in $2 \mathrm{ml}$ of $40 \mathrm{~mm}$ acetate buffer $(\mathrm{pH} \mathrm{6.0)}$ ) at $30^{\circ} \mathrm{C}$. At the indicated time intervals, portions of the reaction mixtures were withdrawn and the reducing sugars produced were determined with glucose as the standard. $\mathrm{O}-\mathrm{O}$, amylopectin; --- amylopectin $\beta$-LD; $\times---\times$, pullulan; $\triangle-\triangle$, phytoglycogen; $\Delta--\mathbf{\Delta}$, phytoglycogen $\beta$-LD; $\square-\square$, oyster glycogen; $\square--\square$, oyster glycogen $\beta$-LD.

indicate unequivocally that it is a debranching enzyme of the isoamylase type. Except for the substrate specificity, the potato isoamylase has many properties different from those of Pseudomonas isoamylase. ${ }^{2)}$ For example, it has a higher molecular weight (MW of 90,000 daltons for Pseudomonas isoamylase), a higher optimum $\mathrm{pH}$ (opt. $\mathrm{pH}$ of 3.5) and a requirement for sulfhydryl regents (no $\mathrm{SH}$ requirement). Data on the molecular weight of the potato isoamylase, however, are rather complex and we have not yet obtained a conclusive value.

Isoamylase has been found and isolated only from microorganisms, $\left.{ }^{23} 27\right)$ and higher plants are generally considered to have only a debranching enzyme of the pullulanase ( $R$ enzyme) type. A report of Manners and Rowe $^{8)}$ is the exception of the above facts. They reported the separation of R-enzyme 


\section{A B}

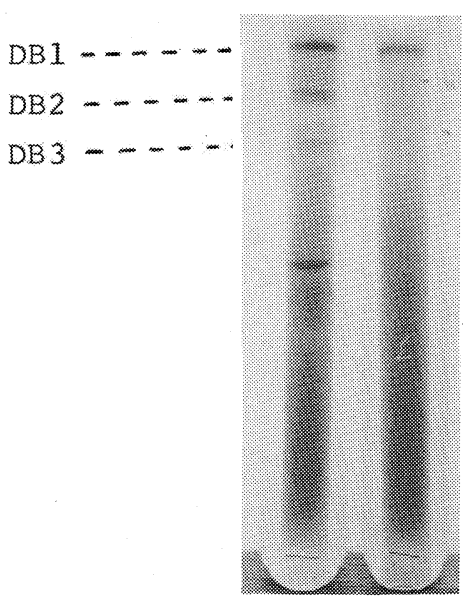

Fig. 11. Zymograms of Potato Crude Extracts and the pH 5 ppt in Table II.

Two hundred $\mu$ l of each sample was subjected to polyacrylamide gel electrophoresis according to the method of Davis $^{16)}$ except that gels contained $0.25 \%$ amylopectin. After the electrophoresis, gels were incubated in $50 \mathrm{~mm}$ acetate buffer $(\mathrm{pH} 6.0)$ at $30^{\circ} \mathrm{C}$ for $1 \mathrm{hr}$ and then stained with $0.02 \% \mathrm{I}_{2}-0.2 \% \mathrm{KI}$ solution. Bands 1,2 and 3 showing increased iodine staining suggest the presence of three debranching enzymes in potato tubers. A, crude extracts; B, pH 5 ppt shown in Table II.

(which acts only on amylopectin) and isoamylase (which acts both on glycogen and on amylopectin) from sweet corn. However, their isoamylase preparation debranched phytoglycogen only to a limited extent leaving "isodextrin."

Therefore, we consider it should rather be classified as an R-enzyme.

In the previous paper, ${ }^{9)}$ we reported the presence of a debranching enzyme of the isoamylase type in addition to 2 R-enzymes in potato tubers. In the present work, we isolated and purified it and examined its substrate specificity to prove it to be an isoamylase.

Whereas potato tubers are one of the higher plants in which R-enzyme was first discovered, its isoamylase has remained to be discovered for a long time. This is partly due to the difficulty in detecting isoamylase selectively in the presence of $\mathrm{R}$-enzyme in crude extracts. We have no substrate with which isoamylase can be assayed selectively. Pullulan is a widely used substrate in the study of debranching enzymes in higher plants, but with this substrate one can detect only R-enzyme and cannot find an isoamylase which scarcely acts on this substrate. As reported previously, ${ }^{9}{ }^{9}$ we detected isoamylase in addition to R-enzyme in potato tubers by preparing a zymogram of crude extracts. The typical zymogram shown in Fig. 11 indicates that there are 3 bands with debranching activities. Of these 3 bands, DB1 was identified as an isoamylase and purified in the present study and DBs 2 and 3 were identified as R-enzyme. The technique of zymography seems to be the only method to detect isoamylase and R-enzyme distinctively in crude extracts of potato tubers.

Different from Pseudomonas isoamylase, ${ }^{2)}$ potato isoamylase is quite unstable in the absence of a sulfhydryl reagent. This is another reason for the fact that isoamylase has not been detected for a long time. The presence of a sulfhydryl reagent is essential for the homogenizing procedure to obtain crude extracts. Crude extracts prepared without this reagent showed no activity even on the addition of the reagent afterwards. During the subsequent purification procedures, isoamylase was inactivated whenever the sulfhydryl reagent was removed, but the activity was restored on the addition of the reagent in this case. In studies on potato debranching enzyme hitherto reported, a sulfhydryl reagent was not used in the purification procedures and therefore isoamylase is supposed to have been inactivated even if it has been extracted in the first step of purification.

As discussed above, potato tubers are the only higher plant material in which isoamylase was detected. Although the isoamylase reported by Manners and Rowe ${ }^{8)}$ is not conclusive, it seems quite reasonable that sweet corn contains isoamylase as this plant has phytoglycogen, which is not debranched completely by the known R-enzyme. Attempts to detect isoamylase in cereals such as barley and rice by the zymographic method described above were unsuccessful because of the high $\alpha$ - 
amylase activity present in the crude extracts. However, some wild relatives to Solanum tuberosum L., Solanum demmisum, S. rybinii, $S$. andigena, S. stenotomum Y. and $S$. phureja, all showed the same zymographic pattern as shown in Fig. 11 (data not shown). This suggests that they also contain isoamylase in addition to R-enzyme.

The enzymic mechanism of starch breakdown in potato tubers during their sprouting is not known. Cereals contain a large amount of $\alpha$-amylase which is known to play a central role in the in vivo breakdown of starch during their germination. On the contrary, potato tubers contain little or no $\alpha$-amylase although they contain a large amount of phosphorylase which cannot digest potato starch granules. The physiological role of the potato isoamylase is not known as yet. To reveal this is a quite interesting aspect for further study of this enzyme.

Acknowledgments. The authors are grateful to Dr. K. Asama of the Konsen Agricultural Experimental Station for the generous supply of tubers of wild relatives of Solanum tuberosum L. We wish to express our thanks to Professor I. Maeda of Konan Women's Junior College for his helpful advice and for generously providing us with $\beta$ limit dextrins. Thanks are also due to Dr. D. J. Manners of Herriot-Watt University of Edinburgh, England, for his useful discussions in the course of preparation of this manuscript.

\section{REFERENCES}

1) E. Y. C. Lee and W. J. Whelan, "The Enzymes," Vol. V, ed. by P. D. Boyer, Academic Press Inc., New York, N. Y., 1971, p. 191.

2) K. Yokobayashi, A. Misaki and T. Harada, Biochim.
Biophys. Acta, 212, 458 (1970).

3) P. N. Hobson, W. J. Whelan and S. Peat, J. Chem. Soc., 1451 (1951).

4) D. J. Manners, Biochem. Soc. Trans., 3, 49 (1975).

5) I. Maeda, J. Nikuni, H. Taniguchi and $M$. Nakamura, Carbohydr. Res., 61, 309 (1978).

6) J. Yamada and M. Izawa, Agric. Biol. Chem., 43, 37 (1979).

7) K. Iwaki and H. Fuwa, Agric. Biol. Chem., 45, 2683 (1981).

8) D. J. Manners and K. L. Rowe, Carbohydr. Res., 9, 107 (1969).

9) Y. Ishizaki, H. Taniguchi and M. Nakamura, Agric. Biol. Chem., 42, 2433 (1978).

10) Y. Ishizaki, H. Taniguchi and Y. Maruyama and M. Nakamura, Denpun Kagaku, J. Jpn. Soc. Starch Sci., 30, 19 (1983).

11) M. Somogyi, J. Biol. Chem., 195, 19 (1952).

12) N. Nelson, J. Biol. Chem., 153, 375 (1944).

13) H. Fuwa, J. Biochem., 41, 583 (1954).

14) M. Dubois, K. A. Gilles, J. K. Hamilton, P. A. Rebers and F. Smith, Anal. Chem., 28, 350 (1956).

15) O. H. Lowry, N. J. Rosebrough, A. L. Farr and R. J. Randall, J. Biol. Chem., 193, 265 (1951).

16) B. J. Davis, Ann. N. Y. Acad. Sci., 121, 404 (1964).

17) O. Gabriel and S-F. Wang, Anal. Biochem., 27, 545 (1969).

18) K. Weber and M. Osborn, J. Biol. chem., 244, 4406 (1969).

19) K. Kainuma and D. French, FEBS Lett., 5, 257 (1969).

20) W. E. Trevelyan, D. P. Procter and J. S. Harrison, Nature, 166, 444 (1950).

21) L. Sundberg and J. Porath, J. Chromatogr., 90, 87 (1974).

22) P. Vretblad, FEBS Lett., 47, 86 (1974).

23) B. Maruo and T. Kobayashi, Nature, 167, 606 (1951).

24) Z. Gunja-Smith, J. J. Marshall, E. E. Smith and W. J. Whelan, FEBS Lett., 12, 96 (1970).

25) H. Urlaub and G. Wöber, FEBS Lett., 57, 1 (1975).

26) R. Jeanningros, N. Creuzet-Sigal, C. Frixon and J. Cattaneo, Biochim. Biophys. Acta, 438, 186 (1976).

27) H. H. Sato and Y. K. Park, Stärke, 32, 132 (1980). 